\title{
Polymorphic microsatellite loci for the cardinal fish (Apogon imberbis)
}

\author{
J. A. Galarza $\&$ S. Roques $\&$ J. Carreras-Carbonell $\mathbb{E}$ \\ E. Macpherson $\&$ G. F. Turner \& C. Rico
}

\begin{abstract}
Eight polymorphic microsatellite loci were isolated and characterized for the Cardinal fish (Apogon imberbis), a coastal-reef fish endemic to the Mediterranean Sea. Characterization of 30 Cardinal fish individuals form the western Mediterranean showed moderate to high allelic diversity ranging from 6 to 19 alleles per locus. Two loci showed significant departures from Hardy-Weinberg equilibrium presumably due to null alleles. No evidence of linkage disequilibrium was found for any locus pairwise comparasions. This microsatellite set could be useful for any basic population genetic studies of this species.
\end{abstract}

Keywords Microsatellite - Apogon imberbis . Cardinal fish $\cdot$ Apogonidae

Cardinal fishes are coastal-reef marine fish of the genus Apogon. This genus comprises a large number of species (174) distributed from the tropical Indo-West

J. A. Galarza · G. F. Turner

Department of Biological Sciences, University of Hull, HU6 7RX Hull, UK

S. Roques · C. Rico

Estació n Biológica Doñ ana (CSIC), Av. Ma. Luisa S/N, 41013 Sevilla, Spain

J. Carreras-Carbonell · E. Macpherson

Centre d'Estudis Avanç ats de Blanes (CSIC), Carrer d'accés

a la Cala Sant Francesc, núm.14, 17300 Blanes,

Catalunya, Spain

J. A. Galarza (\&)

Av. Maria Luisa S/N, Pabelló n del Perú, Seville, Spain

e-mail: j.a.galarza@ebd.csic.es
Pacific to the Atlantic Ocean and the Mediterranean Sea (Kuiter and Kozawa 1999). However, only one species, Apogon imberbis, exists within the Mediterranean Sea (Tortonese 1986). All species appear to have a peculiar reproductive strategy in which internal fertilization is achieved by transferring the sperm into the oviduct of the female through the male's ventral fins (Thresher 1984). The fertilized eggs are then released by the female and picked up by the male who broods them in his mouth until hatching. This form of male parental care has probably been responsible for the considerable interest in the genus, resulting in studies of mating behavior (Kuwamura 1983), filial cannibalism (Smith 1992), gamete biology (Lahnsteiner 2003), parental care effort (Okuda 2001) and molecular phylogeny (Mabuchi et al. 2006). Little attention, however, has been paid to the Mediterranean species for which only one study covering basic aspects of its reproductive behavior and growth rate pattern is available (Garnaud 1962). Furthermore, nuclear genetic information is scarce with just a single study reporting variability at nuclear loci for a single species of the genus (MillerSims et al. 2004). Here, we report the characterization of eight microsatellite loci developed in $A$. imberbis with the aim of evaluate dispersal strategies in this marine mouth-brooding fish.

Microsatellite markers were identify through the development of an enriched genomic library as described in Glenn et al (2000). DNA was extracted from 10 individuals from the Western Mediterranean by the phenol-chloroform method (Sambrook et al. 1989). Simultaneous restriction-ligation of genomic DNA was carried out using Rsal restriction enzyme and double stranded linker-adapted primers according to Hamilton et al (1999). Ligated DNA was size selected 
Table 1 Characterization of 8 Cardinal fish (Apogon imberbis) microsatellite loci $(\mathrm{N}=30)$

\begin{tabular}{|c|c|c|c|c|c|c|c|c|}
\hline $\begin{array}{l}\text { Locus/Gen- } \\
\text { Bank } \\
\text { Accession } \\
\text { No. }\end{array}$ & Locus & $\begin{array}{l}\text { Repeat } \\
\text { motif }\end{array}$ & 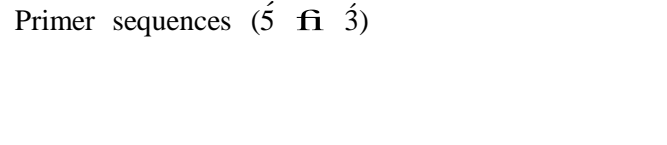 & $\begin{array}{l}\text { Number } \\
\text { of } \\
\text { alleles }\end{array}$ & $\begin{array}{l}\text { Allele } \\
\text { size } \\
\text { (bp) }\end{array}$ & $\mathrm{H}_{\mathrm{O}}$ & $\mathrm{H}_{\mathrm{E}}$ & Fis \\
\hline DQ822534 & Aimb2 & $(\mathrm{CA})_{12}$ & $\begin{array}{l}\text { F: FAM-AGCCGGTTCCTTTAGAGCATTCAA } \\
\text { R: -GAGGCGTTTAGAGTGTGAGAAGGA }\end{array}$ & 6 & $\begin{array}{r}341- \\
355\end{array}$ & 0.550 & 0.751 & 0.273 \\
\hline DQ822535 & Aimb14 & $(\mathrm{GT})_{21}$ & $\begin{array}{l}\text { F: NED-CACCCCACACTACATGCCCTTGAA } \\
\text { R: -GCTGGCTGGCCTAGTTTGGGTCTC }\end{array}$ & 11 & $\begin{array}{l}316- \\
358\end{array}$ & 0.800 & 0.876 & 0.084 \\
\hline DQ822536 & Aimb17 & $(\mathrm{CTAT})_{23}$ & $\begin{array}{l}\text { F: NED-TCGCTGGTGTTGTCTAATGCATTC } \\
\text { R: -TGGGGAAGGAGAGCGATGCAGAAC }\end{array}$ & 19 & $\begin{array}{l}120- \\
200\end{array}$ & 0.800 & 0.961 & 0.166 \\
\hline DQ822537 & Aimb22 & $(\mathrm{CA})_{14}$ & $\begin{array}{l}\text { F: PET-ACCGCTGCTGTCAGTCCTGTCACA } \\
\text { R :- AACCGAGGCTGTTCCCATCAAATG }\end{array}$ & 6 & $\begin{array}{r}447- \\
457\end{array}$ & 0.300 & 0.746 & $0.599 *$ \\
\hline DQ822538 & Aimb28 & $(\mathrm{CA})_{3} \mathrm{CT}(\mathrm{CA})_{9}$ & $\begin{array}{c}\text { F: PET-CCGTTCTGCTCTGATTGGTCAACT } \\
\text { R :- TCCTTTTGGCGCTGATTAGTTCAC }\end{array}$ & 8 & $\begin{array}{r}254- \\
272\end{array}$ & 0.850 & 0.811 & -0.052 \\
\hline DQ822539 & Aimb29 & $(\mathrm{CA})_{15}$ & $\begin{array}{l}\text { F: FAM-CTTGCCGTTTTTGCTACTATGTTCC } \\
\text { R: -GCTGATTTTAAGCTACATTCTACCT }\end{array}$ & 13 & $\begin{array}{r}198- \\
232\end{array}$ & 0.650 & 0.866 & $0.253^{*}$ \\
\hline DQ822540 & Aimb41 & $(\mathrm{GT})_{16}$ & $\begin{array}{l}\text { F: VIC-ACGGCTCAGAAGATGGTCCACACA } \\
\text { R: -GTGCCATCCAATCTGTCCATCATA }\end{array}$ & 13 & $\begin{array}{l}335- \\
377\end{array}$ & 0.850 & 0.850 & -0.002 \\
\hline DQ822541 & Aimb74 & $(\mathrm{CA})_{11} \mathrm{TA}(\mathrm{CA})_{3}$ & $\begin{array}{l}\text { F: VIC-CACCACAATAGTTAAATGCTCCCT } \\
\text { R: -CTTCGCATCAGGGGTTAATCTCAA }\end{array}$ & 6 & $\begin{array}{r}210- \\
240\end{array}$ & 0.650 & 0.680 & 0.035 \\
\hline
\end{tabular}

GenBank Accession No., Locus name, repeat motif, fluorescent dye-primer sequence, number of alleles, Allele size range, $\mathrm{H}_{\mathrm{O}}$ : observed heterozygosity, $\mathrm{H}_{\mathrm{E}}$ : expected heterozygosity under Hardy-Weinberg equilibrium, $\mathrm{F}_{\mathrm{IS}}$ : inbreeding coefficient, ${ }^{*} \mathrm{P}<0.05$

and enriched by magnetic bead selection with a biotinlabeled probe mixture consisting of $(\mathrm{GT})_{10}$ and $(\mathrm{CT})_{10}$ at $10 \mathrm{IM}$ each. Enriched DNA was eluted in $200 \mathbf{1 l}$ $\mathrm{dH}_{2} \mathrm{O}$ from the bead probes and concentrated by vacuum centrifugation to a final concentration of $\sim 100$ ng/1l. Recovered DNA was then purified and cloned using pGEM-T Easy Vector II (Promega). A total of 56 positive clones were screened and checked for inserts using ABI PRISM BigDye Terminator Cycle kit (Applied Biosystems) and resolved on an ABI 3100 Genetic Analyser (Applied Biosystems). Primer pairs for eight potential usable microsatellite loci were designed using OLIGO 6.4 software. Polymorphism was tested by multiplex PCR reactions performed in 2511 total volume, which include $50 \mathrm{ng}$ of DNA, $2 \mathrm{mM}$ of $\mathrm{MgCl}_{2}, 0.751 \mathrm{M}$ of each primer, $2001 \mathrm{M}$ dNTP's, $1 \mathrm{X}$ reaction buffer [75 mM Tris-Hcl, $20 \mathrm{mM}\left(\mathrm{NH}_{4}\right)_{2} \mathrm{SO}_{4}$ ] and 0.5 units Taq polimerase (BIOTAQ). Reaction conditions were as follows: an initial denaturation step of $5 \mathrm{~min}$ at $95^{\circ} \mathrm{C}$, eight cycles consisting of $30 \mathrm{~s}$ at $92^{\circ} \mathrm{C}$, $30 \mathrm{~s}$ at $53.5^{\circ} \mathrm{C}$ annealing temperature, $30 \mathrm{~s}$ at $72^{\circ} \mathrm{C}$ followed by an additional twenty eight cycles at $55.5^{\circ} \mathrm{C}$ annealing temperature. Microsatellite variability was assessed in 30 individuals from the western Mediterranean. Individuals were genotyped by assessing allele size on an ABI 3100 Genetic Analyser (Applied Biosystems) using forward primers labelled with FAM (Sigma) and NED, PET and VIC (Applied Biosystems). Allele scoring was carried out using GENEMAPPER version 3.5 software (Applied Biosystems). Expected and observed values for heterozygosity were determined using ARLEQUIN V.2.0 (Schneider et al. 2000). The number of alleles per locus, allele size range as well as deviations from Hardy-Weinberg expectations and linkage disequilibrium between pairs of loci were estimated using FSTAT V.2.9 (Goudet 1995). All loci were polymorphic, the total number of alleles per locus and heterozygosities estimates are listed in Table 1. We found no evidence of linkage disequilibrium between locus pairs. Two loci showed significant departures from Hardy-Weinberg equilibrium (Aimb22, Aimb29). This could be due to the presence of null alleles or the inclusion of individuals from different populations in the analysis.

Acknowledgements This work was funded in part by the Mexican Council for Science and Technology CONACyT and Junta de Andalucia Ref. 2003X880_1. The authors would like to thank Diego Moreno and Chemi for their help in collecting the samples.

\section{References}

Garnaud J (1962) Monographie de l'Apogon méditerranéen, Apogon imberbis (Linné ) 1758. Bull Inst Oceanogr (Monaco) $1248: 1-83$

Glenn TC, Cary T, Dust M, Hauswaldt S, Prince K, Clifton R, Shute I (2000) Microsatellite Isolation. http://www.uga.edu/ srel/DNA_Lab/protocols.htm

Goudet J (1995) F_STAT (2.9.3) a program for IBM compatible PCs to calculate Weir and Cockerman's (1984) estimators of F-statistics. J Heredity 86:485-486

Hamilton MB, Pincus EL, Di Fiore A, Flesher RC (1999) Universal linker and ligation procedures for construction of 
genomic DNA libraries enriched for microsatellites. Biotechniques 27:500-507

Kuiter RH, Kozawa T (1999) Pictorial guide to fishes of the Indo-West Pacific, Apogonidae Aquatic Photographics, Australia, 59pp

Kuwamura T (1983) Spawning behaviour and timing of fertilization in the mouthbreeding cardinalfish Apogon notatus. Jpn J Ichthyol 30:61-71

Lahnsteiner F (2003) The spermatozoa and eggs of the cardinal fish. J Fish Biol 62:115-128

Mabuchi K, Okuda N, Nishida M (2006) Molecular phylogeny and stripe pattern evolution in the cardinalfish genus Apogon. Mol Phylogenet Evol 38:90-99

Miller-Sims V, Atema J, Kingsford MJ, Gerlach G (2004) Characterization and isolation of DNA microsatellite primers in the cardinalfish (Apogon doederleini). Mol Ecol Notes 4:336-338

Okuda N (2001) The costs of reproduction to males and females of a paternal mouthbreeding cardinalfish Apogon notatus. J Fish Biol 58:776-787
Sambrook J, Fritsch EF, Maniatis T (1989) Molecular cloning: a laboratory manual. 2nd edn Cold Spring Harbor Laboratory Press, New York

Schneider S, Roessli D, Excoffier L (2000) ARLEQUIN: A software for population genetics data analysis Ver.2.0. Genetics and Biometry Laboratory, University of Geneva, Switzerland

Smith C (1992) Filial cannibalism as a reproductive strategy in care giving teleost? Neth J Zool 42:607-613

Thresher RE (1984) Reproduction in Reef Fishes. T.F.H. Publications, New Jersey

Tortonese E (1986) Apogonidae. In: Whitehead PJP, Bauchot ML, Hureau JC, Nielsen J, Tortonese (eds), Fishes of the north-eastern Atlantic and the Mediterranean UNESCO, Paris, p 804 